\title{
High metal contents in the fan mussel Pinna nobilis in the Balearic Archipelago (western Mediterranean Sea) and a review of concentrations in marine bivalves (Pinnidae)
}

\author{
Maite Vázquez-Luis ${ }^{1}$, Mercè Morató ${ }^{1}$, Juan Antonio Campillo ${ }^{2}$, Carlos Guitart ${ }^{2}$, \\ Salud Deudero ${ }^{1}$ \\ ${ }^{1}$ Instituto Español de Oceanografía (IEO), Centro Oceanográfico de Baleares, Muelle de Poniente s/n, \\ 07015 Palma de Mallorca, Spain. E-mail: maitevazquezluis@ gmail.com \\ ${ }^{2}$ Instituto Español de Oceanografía (IEO), Centro Oceanográfico de Murcia, c/ Varadero 1, 30740 San Pedro del Pinatar, \\ Murcia, Spain.
}

\begin{abstract}
Summary: Concentrations of metals $(\mathrm{Cd}, \mathrm{Cu}, \mathrm{Hg}, \mathrm{Pb}$ and $\mathrm{Zn})$ in the marine bivalve Pinna nobilis at several coastal locations of Majorca and the Cabrera Islands (Mediterranean Sea) were investigated. The elevated concentrations of metals found in the soft tissues of $P$. nobilis indicate high bioaccumulation factors. All concentrations and the calculated metal pollution index showed significant differences between sites, with particularly high concentrations in the Cabrera Archipelago, a marine protected area (MPA). The datasets were evaluated with the limited information published in the literature for Pinnidae species worldwide. In benthic $P$. nobilis, concentrations of $\mathrm{Cd}, \mathrm{Cu}$ and $\mathrm{Zn}$ are more than 30 times higher and $\mathrm{Hg}$ and $\mathrm{Pb}$ concentrations are 4 and 7 times higher, respectively, than concentrations in other bivalve species, such as Mytilus galloprovincialis (Mytilidae). These observations from species inhabiting nearby ecological habitats of the coastal environment (Pinnidae vs. Mytilidae) are also discussed in the context of current marine monitoring strategies and assessments.
\end{abstract}

Keywords: trace metal; bivalve; mollusc; bioaccumulation; Pinnidae, Mytilidae.

Alto contenido de metales en el molusco Pinna nobilis en el Archipiélago Balear (Mediterráneo occidental) y una revisión de las concentraciones en bivalvos marinos (Pinnidae)

Resumen: Se investigaron las concentraciones de metales ( $\mathrm{Cd}, \mathrm{Cu}, \mathrm{Hg}, \mathrm{Pb}$ y $\mathrm{Zn}$ ) en el bivalvo marino Pinna nobilis en diferentes localidades costeras de las Islas de Mallorca y Cabrera (Mar Mediterráneo). Las elevadas concentraciones de metales que se encontraron en los tejidos blandos de $P$. nobilis revelaron una elevada bioacumulación. Las concentraciones de metales estudiadas, así como el índice de contaminación por metales (ICM) mostraron diferencias significativas entre los sitios, con concentraciones particularmente altas en el archipiélago de Cabrera, un área marina protegida (AMP). Se realizó una revisión bibliográfica de la escasa información publicada sobre las especies de la familia Pinnidae a nivel mundial. En comparación con otras especies de bivalvos, como Mytilus galloprovincialis (Mytilidae), la especie bentónica P. nobilis presentó concentraciones más de 30 veces superiores para $\mathrm{Cd}, \mathrm{Cu}$ y $\mathrm{Zn}$; y hasta 4 y 7 veces para $\mathrm{Hg}$ y $\mathrm{Pb}$, respectivamente. La información recabada sobre estas especies que habitan en ecosistemas costeros (Pinnidae vs. Mytilidae) es discutida en el contexto de las actuales estrategias marinas de seguimiento y evaluación.

Palabras clave: metales traza; bivalvo; molusco; bioacumulación; Pinnidae, Mytilidae.

Citation/Como citar este artículo: Vázquez-Luis M., Morató M., Campillo J.A., Guitart C., Deudero S. 2016. High metal contents in the fan mussel Pinna nobilis in the Balearic Archipelago (western Mediterranean Sea) and a review of concentrations in marine bivalves (Pinnidae). Sci. Mar. 80(1): 000-000. doi: http://dx.doi.org/10.3989/scimar.04255.24B

Editor: X.A. Álvarez-Salgado.

Received: April 20, 2015. Accepted: July 31, 2015. Published: December 11, 2015.

Copyright: () 2016 CSIC. This is an open-access article distributed under the Creative Commons Attribution-Non Commercial Lisence (by-nc) Spain 3.0. 


\section{INTRODUCTION}

Natural and anthropogenic processes that introduce chemical substances above background ecosystem levels and that may cause ecosystem deterioration are considered as sources of pollution in the marine environment (Clark 2001). It is well known that coastal areas receive large amounts of trace metal inputs from various sources, and some metals are regarded as serious pollutants due to their anthropogenic origin, bioaccumulation and toxicity to marine organisms (Lafabrie et al. 2008). Metal contaminants can be directly or indirectly accumulated in different marine species and cause several biological effects, ranging from molecular dysfunctions to ecological changes depending on the exposure and tolerance levels (Van der Oost et al. 2003). Particularly, filter-feeder marine bivalve molluscs (e.g. mussels, oysters, etc.) accumulate metals either directly from dissolved concentrations in the water column or indirectly via ingestion of metal-bounded suspended particles from the surrounding environment. Bivalves have been shown to be valuable 'sentinel organisms' because of their limited metabolic capacity of metal excretion and their worldwide distribution (Goldberg 1975, Goldberg and Bertine 2000), and they have therefore been used to monitor and assess coastal pollution for decades (O'Connor and Beliaeff 1995 , O'Connor and Launstein 2006, Benedicto et al 2011, Besada et al. 2014, Neira et al. 2015).

Many studies on the occurrence of metals in different species and habitats of the Mediterranean Sea have been investigated primarily using the bivalve mollusc Mytilus galloprovincialis (Andral et al. 2004, Deudero et al. 2009, Benedicto et al. 2011) and benthic invertebrate species such as Venus verrucosa, Litophaga litophaga, Ostrea edulis and Chamelea gallina (Deudero et al. 2007). Similarly, following the transport, distribution and fate of metal species in the marine environment, many benthic organisms could accumulate them and also be targeted as sentinels of metal contamination. Thus, benthic animals and plants are clearly under the influence of anthropogenic pressures in the marine environment (Solis-Weiss et al. 2004, Deudero et al. 2007). In this context, the species Pinna nobilis Linnaeus 1758 is a benthic species endemic to the Mediterranean Sea that inhabits seagrass meadows, especially those of $P$. oceanica, from shallow areas down to $60 \mathrm{~m}$ bottom depth (García-March 2003). In the Balearic Archipelago, a high bioaccumulation of polyaromatic hydrocarbons in $P$. nobilis has been confirmed in the framework of a post-oil spill environmental assessment evaluation (Sureda et al 2013).

The family Pinnidae Leach 1819 are filter-feeder marine bivalve molluscs with a long triangular shape and fragile shells with the pointed end anchored in the substrate using the byssus threads. $P$. nobilis is the largest Mediterranean bivalve and one of the biggest worldwide (Zavodnik et al. 1991), with shell lengths usually of $15-35 \mathrm{~cm}$ and exceptionally up to $120 \mathrm{~cm}$ (Schultz et al. 2013). This family includes two genera (Pinna and Atrina, Lemer et al. 2014) with 61 species described worldwide (WoRMS 2014). With regard to substrate types and habitats, Pinnidae species have been found in mud, silt, sand, coral, rocks, seagrass meadows and mangrove swamps (Schultz et al. 2013). Pinnids are distributed from the shoreline, at very shallow depths of a few decimetres, to the bathyal zone down to 600 metres. In the Mediterranean Sea, $P$. nobilis is a protected species under both Annex II of the Barcelona Convention (SPA/BD Protocol 1995) and Annex IV of the EU Habitats Directive (EU Directive 2007), so scientific studies are required to understand and assess the current status of $P$. nobilis populations for future management and conservation strategies.

The datasets of metal concentrations are scarce and spread over a few geographical locations in the Mediterranean basin. So far, five studies have reported the accumulation of metals in P. nobilis in the Mediterranean: two were carried out in Greece (Catsiki and Katsilieri 1992, Catsiki et al. 1994), one in France (Mathew et al. 1996), and two recently in Tunis (Rabaoui et al. 2014, Jebali et al. 2014). These studies determined various metals in different parts of the specimens within a variety of field experiment approaches. The present study aims to contribute to the existing knowledge by (i) determining the concentration of metals in the soft tissues of $P$. nobilis in the Balearic Archipelago; and (ii) providing the first bibliographic review on levels of metals for Pinnidae species by reviewing worldwide datasets from the literature.

\section{MATERIALS AND METHODS}

\section{Study area and sample collection}

The study was conducted in the Spanish Balearic Archipelago in the western Mediterranean Sea. Two sets of samples were collected in the Andratx and Magaluf coastal areas in Mallorca Island and a third set of samples in Santa Maria Bay located in the Cabrera Archipelago, a small group of unoccupied islands located southeast from Majorca. The Cabrera Archipelago was established as a marine protected area (MPA) in 1991 , with an area of about $100.21 \mathrm{~km}^{2}$, of which $87 \%$ covers marine surface and comprises 19 small islands. The three sampling areas were selected taking into account the potential human impact and degree of protection. The Port of Andratx (recreational harbour) and Magaluf coastal towns are both situated in an area with a number of anthropogenic impacts, from agricultural uses to urban development due to increasing tourism activities, with the consequent modification of the coastline. By contrast, Santa Maria Bay located in the Cabrera Marine-Terrestrial National Park (an MPA) was selected to represent a pristine area (Fig. 1). The samples of $P$. nobilis ( $\mathrm{n}=14 ; 4$ in Andratx, 4 in Magaluf and 6 in S. Maria Bay) were collected manually with scuba divers in shallow waters $(8-12 \mathrm{~m}$ depth) over seagrass meadows of $P$. oceanica at each study site in October 2011. The shell size (maximum width) ranged from 13.7 to $22.0 \mathrm{~cm}$. After collection, the whole soft tissues of $P$. nobilis were dissected at the laboratory from each individual, placed in clean glass jars, weighed, and stored frozen at $-20^{\circ} \mathrm{C}$. 

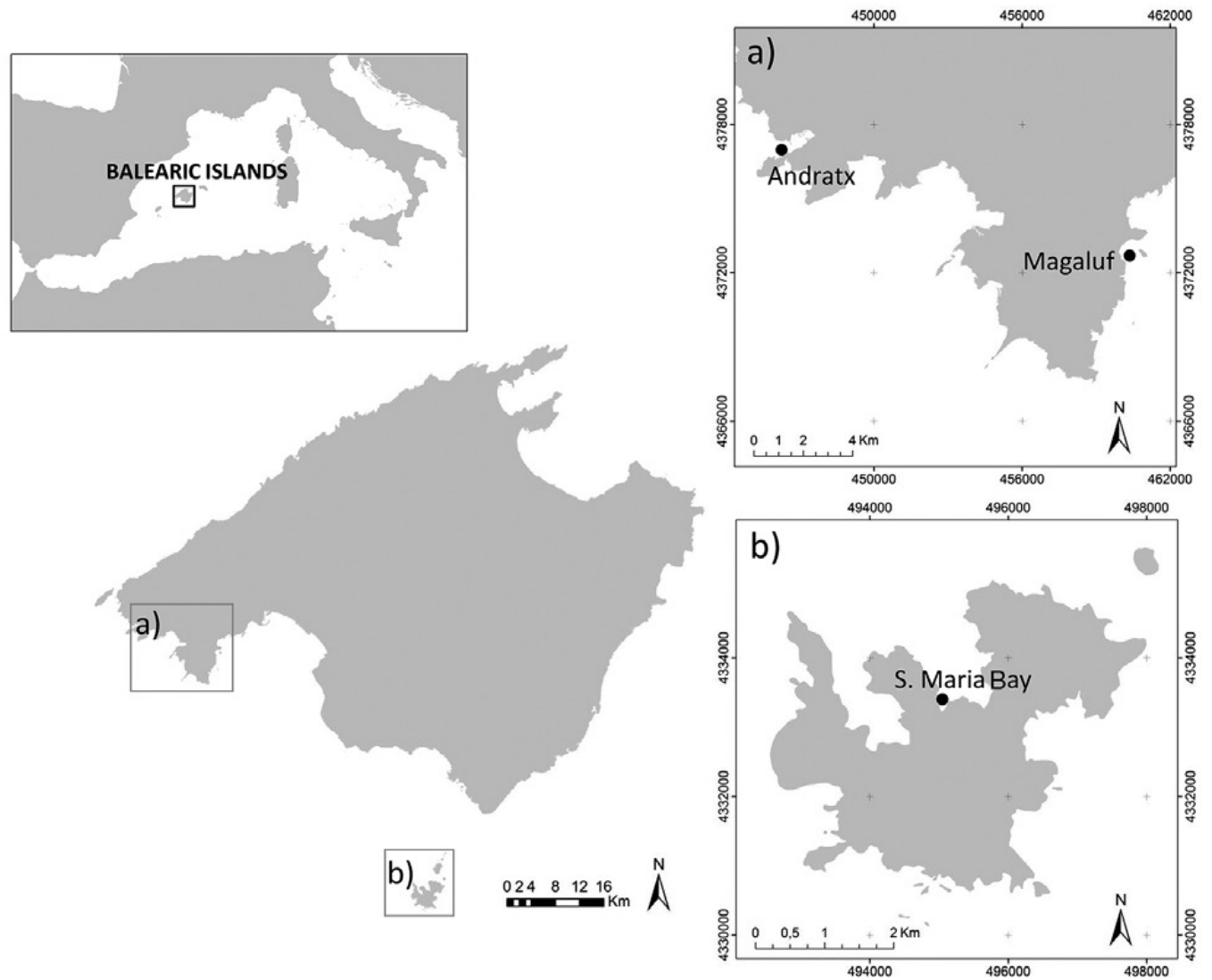

Fig. 1. - Location of the collection sites: a) Andratx (harbour) and Magaluf (coastal town) on Mallorca Island, and b) Santa Maria Bay in the Cabrera Marine-Terrestrial National Park.

\section{Trace metal determinations}

The collected samples were further processed at the trace metal laboratory facilities to determine cadmium $(\mathrm{Cd})$, copper $(\mathrm{Cu})$, zinc $(\mathrm{Zn})$, mercury $(\mathrm{Hg})$ and lead $(\mathrm{Pb})$. Each sample was defrosted, mixed, homogenized (ULTRA-Turrax ${ }^{\circledR}$ T25, IKA Labortechnik) and lyophilized (Christ ALPHA 1-4, B.Braun Biotech International) to calculate the wet/dry weight ratio for

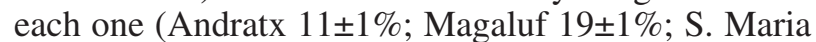
Bay $19 \pm 2 \%$ ). The dried sample material was further crumbled and powdered using a centrifugal ball mill (Fritsch Pulverisette, Model 06.102) with 30-, 20- and 10 -mm diameter agatha balls for 15 minutes, and finally bottled in clean small amber glass jars.

The total metal determinations were performed using atomic absorption spectrometry (AAS) instrumental techniques. Total mercury was determined using a direct-sample, solid-combustion, atomic-absorption mercury analyser (Advanced Mercury Analyser-AMA 254, LECO Corporation). Samples of about $50 \mathrm{mg}$ were placed (without prior digestion) in the nickel sample boats for direct analysis in a combustion/catalyst tube followed by amalgamation, which collects and releases the mercury species into the detector. A digestion step procedure was used for $\mathrm{Cd}, \mathrm{Cu}, \mathrm{Zn}$ and $\mathrm{Pb}$ determinations using a microwave-assisted oven (Milestone, ETHOS Pro) prior to instrumental determinations. About $300 \mathrm{mg}$ of sample was weighed into the microwave vessels and prepared for digestion using 6 $\mathrm{ml}$ of $\mathrm{HNO}_{3}$ acid (Hiperpur 69\%, Panreac) and $1 \mathrm{ml} \mathrm{ul-}$ trapure deionized water (Milli-Q, Millipore). After the sample digestion, the extract was diluted and adjusted to $25 \mathrm{~mL}$ in polypropylene volumetric flasks ready for analysis by AAS. $\mathrm{Cu}, \mathrm{Zn}$ and $\mathrm{Pb}$ were determined by Flame-AAS (Perkin-Elmer, AAnalyst 100) using a high sensitivity nebulizer for the latter, whilst $\mathrm{Cd}$ was determined by Zeeman GF-AAS (Perkin-Elmer, 4110ZL).

Calibration standards for each metal were prepared from commercial certified solutions (Scharlau, Spain). Non-linear (three to five points) calibrations were used for $\mathrm{Zn}$ (up to $6 \mathrm{mg} \mathrm{L}^{-1}$ ), $\mathrm{Cu}$ (up to $2 \mathrm{mg} \mathrm{L}^{-1}$ ), Cd (up to $10 \mu \mathrm{g} \mathrm{L}^{-1}$ ) and $\mathrm{Pb}$ (up to $2 \mathrm{mg} \mathrm{L}^{-1}$ ). The high values encountered during the sample analysis challenged the analytical methods and most of the samples needed to be diluted: $1 / 10,1 / 2$, and from $1 / 10$ to $1 / 100$ for $\mathrm{Zn}$, $\mathrm{Cu}$ and $\mathrm{Cd}$, respectively. The limits of quantification (LOQ) of the analytical methods were calculated as 0.3 $\mathrm{mg} \mathrm{kg}-1$ for $\mathrm{Zn}$ and $\mathrm{Cu}, 1.0 \mathrm{mg} \mathrm{kg}^{-1}$ for $\mathrm{Pb}, 0.01 \mathrm{mg}$ $\mathrm{kg}^{-1}$ for $\mathrm{Cd}$ and $0.011 \mathrm{mg} \mathrm{kg}^{-1}$ for $\mathrm{Hg}$ (dry weight). A typical instrument run sequence consisted of sensitivity checks, instrument calibration and procedural blanks, followed by matrix reference material and sample measurements. The accuracy and precision of the datasets was evaluated with the certified reference material SRM 2976 (a mussel bivalve mollusc, NIST, USA). QA/QC and data validation were performed, and Cd and $\mathrm{Pb}$ were corrected by procedural blanks and recovery to adjust accuracy deviations. Analytical data was 
Table 1. - QA/QC data (mg kg-1 DW) for the certified reference material SRM 2976 (NIST, USA), accuracy, precision, LOQ and analytical method. SD, standard deviation; RSD, residual standard deviation; LOQ, limit of quantification; F-AAS, flame-atomic absorption spectrometry; GF-AAS, graphite furnace-atomic absorption spectrometry; Solid-AAS, direct solid-sample combustion atomic absorption spectrometry. All concentrations are reported on a dry weight (DW) basis.

\begin{tabular}{cccccc}
\hline $\begin{array}{c}\text { Element-SRM 2976 } \\
\text { (NIST, USA) }\end{array}$ & Certified value \pm SD & $\begin{array}{c}\text { Certified Range } \\
\text { [min.-max.] }\end{array}$ & Mean value \pm SD & RSD (\%) & LOQ/Instrument \\
\hline $\mathrm{Cu}$ & $4.02 \pm 0.33$ & $3.69-4.35$ & $4.11 \pm 0.08$ & 2 & $0.30(\mathrm{~F}-\mathrm{AAS})$ \\
$\mathrm{Zn}$ & $137 \pm 13$ & $124-150$ & $145 \pm 1$ & 1 & $0.3(\mathrm{~F}-\mathrm{AAS})$ \\
$\mathrm{Cd}$ & $0.82 \pm 0.16$ & $0.66-0.98$ & $1.06 \pm 0.01$ & 1 & $0.01(\mathrm{GF}-\mathrm{AAS})$ \\
$\mathrm{Pb}$ & $1.19 \pm 0.18$ & $1.01-1.37$ & $1.79 \pm 0.024$ & 14 & $1.0(\mathrm{~F}-\mathrm{AAS}$, high sensitivity nebulizer) \\
$\mathrm{Hg}$ & $61.0 \pm 3.6$ & $57.4-64.6$ & $61.1 \pm 3.5$ & 6 & $0.011(\mathrm{Solid}-\mathrm{AAS})$ \\
\hline
\end{tabular}

also corrected by the moisture weight content (average: $6.1 \pm 1.0 \%$ ) as usual. Quality assurance results and other analytical information are summarized in Table 1. The external validation of the laboratory analytical procedures is regularly assessed by participation in QUASIMEME (Quality Assurance of Information in Marine Environmental Monitoring in Europe) interlaboratory exercises for trace metal determinations in sediment and biota samples.

\section{Statistical analysis}

In order to test differences of the metal concentrations in $P$. nobilis among sites, a one-way ANOVA was performed (SPSS Statistical Software v17.0). The experimental design included one factor: "Site" (fixed), with three levels (Andratx, Magaluf and S. Maria Bay) for each metal determined. Prior to carrying out the ANOVA, the datasets were tested for normality and homogeneity of variances using Shapiro-Wilk and Levene tests, respectively (significance level, p-value $<0.01)$. Where the variance remained heterogeneous (which was the case for $\mathrm{Cd}$ and $\mathrm{Cu}$ ), the robust ANOVA alternative, the Brown-Forsythe statistic, was used instead of the F statistic. Where ANOVA indicated a significant difference, the source of difference was then identified using the post-hoc Tukey test for $\mathrm{Zn}, \mathrm{Hg}$ and $\mathrm{Pb}$ and the Games-Howell test for $\mathrm{Cd}$ and $\mathrm{Cu}$. Moreover, to allow a comparison between sites taking into account all the metals together, the metal pollution index (MPI) was calculated at each site and also tested with a one-way ANOVA ( $p$-value $<0.01$ ). The MPI formula is $\mathrm{MPI}=\left(\mathrm{C}_{\mathrm{f} 1} \times \mathrm{C}_{\mathrm{f} 2} \ldots \mathrm{C}_{\mathrm{fn}}\right)^{1 / \mathrm{n}}$, where the $\mathrm{C}_{\mathrm{fn}}$ is the $n$ metal concentration in the sample (Usero et al. 2005, Deudero et al. 2007, Lafabrie et al. 2008). Further, multivariate statistical analyses were performed by using a principal component analysis (PCA) and a SIMPER routine to explore the spatial variation of metal bioaccumulation datasets in P. nobilis and determine the contribution (in $\%$ ) of specific metals characterizing differences among sites (PRIMER-E Software v6.0).

\section{RESULTS}

\section{Metals in Pinna nobilis}

Concentrations in $P$. nobilis exhibit significant statistical differences, with large concentration ranges among sampling sites, varying up to one order of magnitude depending on the metal (Table 2 and Figure 2). Significant differences were found for $\mathrm{Cd}$, being higher in S. Maria Bay $(33.9 \%)$ than in Magaluf and Andratx (SIMPER analysis) (Fig. 2a). The highest $\mathrm{Cu}$ levels were found in Magaluf (with a contribution of $42.4 \%$ ) without statistical differences with respect to S. Maria Bay levels, and significant lower levels were only observed in Andratx (Fig. 2b). Zinc levels were found to be statistically different at all three sites, with the highest contribution in Andratx (85.7\%), followed by S. Maria Bay and Magaluf (Fig. 2c). Thus, $\mathrm{Cd}, \mathrm{Cu}$ and $\mathrm{Zn}$ show a maximum concentration occurrence in P. nobilis at independent locations (S. Maria Bay, Magaluf and Andratx, respectively). In contrast, $\mathrm{Hg}, \mathrm{Pb}$, as well as the MPI, showed a similar pattern and less concentration variability, the exception being the Port of Andratx. Differences in contamination were not statistically significant between S. Maria Bay and Magaluf in terms of $\mathrm{Hg}(17.9 \%$ and $21.7 \%$, respectively) and $\mathrm{Pb}(23.9 \%$ and $15.6 \%$, respectively) (Fig. 2d and Fig. 2e). However, the Port of Andratx showed much lower concentrations of $\mathrm{Hg}$ and $\mathrm{Pb}$ and the rest of metals $(\mathrm{Cd}$ and $\mathrm{Cu})$, except $\mathrm{Zn}$. The MPI value (Fig. 2f) also confirmed a significant statistical difference in Andratx than at the other two sites. Figure 3 shows the groups segregated by PCA analysis between sampling sites in relation to metals. It can be observed that $\mathrm{Cu}$ is located near Magaluf data, whilst $\mathrm{Cd}$ and $\mathrm{Zn}$ are close to $\mathrm{S}$. Maria Bay data, with two components explaining the $90.6 \%$ of dataset variability in accordance with the previous ANOVA results. Mean data values and ranges for each metal and location are reported in Table 2 .

\section{Metals in Pinnidae species worldwide}

To compare the metal concentrations determined in $P$. nobilis individuals in this study, the existing scientific literature was reviewed using the ScienceDirect and Scopus databases of Elsevier and the Web of Science database of Thomson Reuters. The bibliographic search was conducted using "pinnidae", "pinna", "atrina", "heavy metals" and "pollution" in different combinations. The results provided 11 research papers focusing on the study of metal concentrations in species of the family Pinnidae, mainly for the genus Pinna (with data for four species) and Atrina (with data for one species) (Table 2). The studies differed mainly in the sample location, the number of metals determined and the parts of the specimens analysed (tissues, gonads, hepatopancreas, gills, etc.). Table 2 summarizes the ranges of metal concentrations reported in Pinnidae species collected worldwide at present time. 

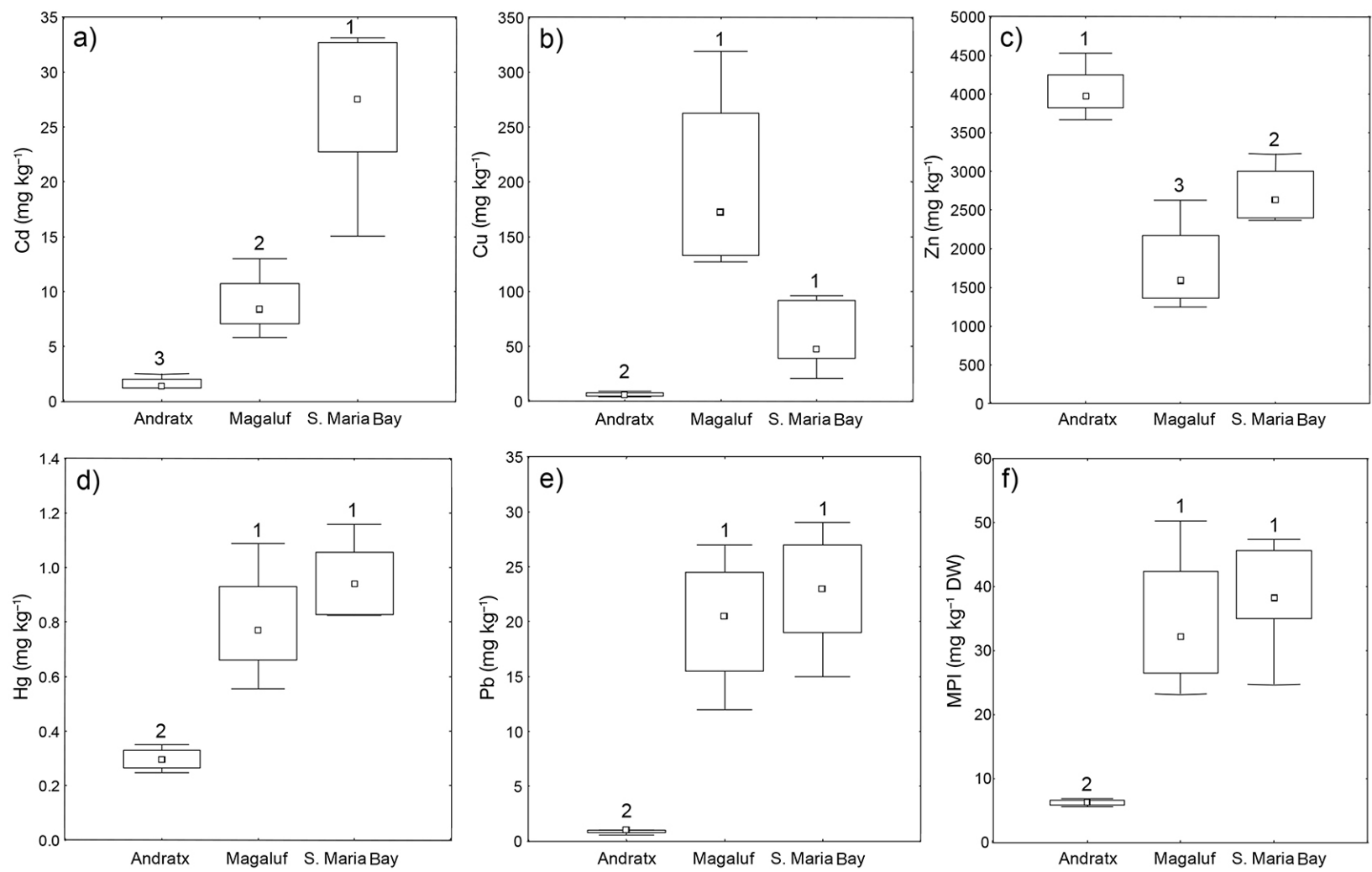

Fig. 2. - Box-plot of metal concentrations (mg/kg DW) determined in the soft tissues of P. nobilis at the sampling sites: a) cadmium, b) copper, c) mercury, d) zinc, e) lead, and f) metal pollution index. Groups numbers are defined by ANOVA post-hoc tests (p<0.01).

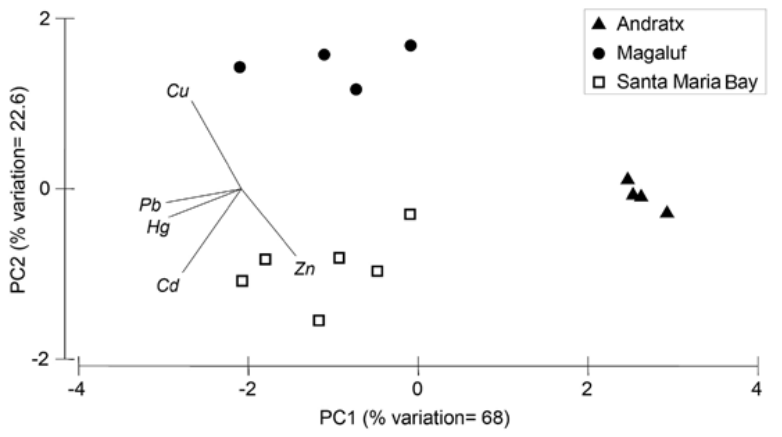

Fig. 3. - PCA results for all metals (Cd, $\mathrm{Cu}, \mathrm{Hg}, \mathrm{Pb}$ and $\mathrm{Zn})$ in $P$. nobilis among sampling sites (Andratx, Magaluf, and Santa Maria Bay) in the Balearic Islands.

\section{Pinna nobilis}

$P$. nobilis was first explored regarding metal concentrations in the Mediterranean Sea by Catsiki and Katsilieri (1992). These authors studied chromium $(\mathrm{Cr})$ concentrations in several parts of $P$. nobilis individuals collected in the Geras Gulf (Greece) and found the highest and lowest values in mantle and muscle tissues, respectively. A second study by Catsiki et al. (1994) with specimens collected in the Geras Gulf and the Kalloni Gulf (Greece) found the same pattern regarding tissue accumulation, although it determined lower metal concentrations in the specimens from the Kalloni Gulf and a higher Cr impact in the Geras Gulf due to additional inputs by tannery effluents. Mathew et al. (1996) determined nine met- als in the extrapallial fluid of two individuals (data in wet weight, Table 2), showing that both hemolymph and extrapallial fluid plasma contained $\mathrm{Mn}$ (II) at concentrations over five orders of magnitude higher than those normally found in seawater. More recently, Rabaoui et al. (2014) studied four metals (Cd, $\mathrm{Hg}, \mathrm{Pb}$ and $\mathrm{Cr}$ ) in different parts of $P$. nobilis among several localities of the Gulf of Gabes (Tunisia). The study reveals that the highest metal contents were recorded in the hepatopancreas. Another recent study (Jebali et al. 2014) explored the metal accumulation and elimination processes in $P$. nobilis with transplanted individuals in a polluted environment (a harbour) and a few individuals transferred back to a decontaminated control area after three months. Five metals $(\mathrm{Cd}, \mathrm{Pb}$, $\mathrm{Zn}, \mathrm{Mn}$ and $\mathrm{Fe}$ ) were measured in three organs over time and showed that from one to three months of exposure are necessary to obtain responses in metal bioaccumulation. The authors also concluded that the studied tissues displayed different metal uptake/ detoxification mechanisms (the latter data not shown in Table 2).

\section{Pinna bicolor}

Maher (1985) studied concentrations of four metals $(\mathrm{Cd}, \mathrm{Cu}, \mathrm{Pb}$ and $\mathrm{Zn})$ in muscle and viscera of five individuals of $P$. bicolor in Australia, and found the highest values in the visceras. Reid and Brand (1989) analysed 21 metal concentrations in granules and the cytosol fraction of different tissues in $P$. bicolor specimens from Australia. Khristoforova et al. (2007) analysed 


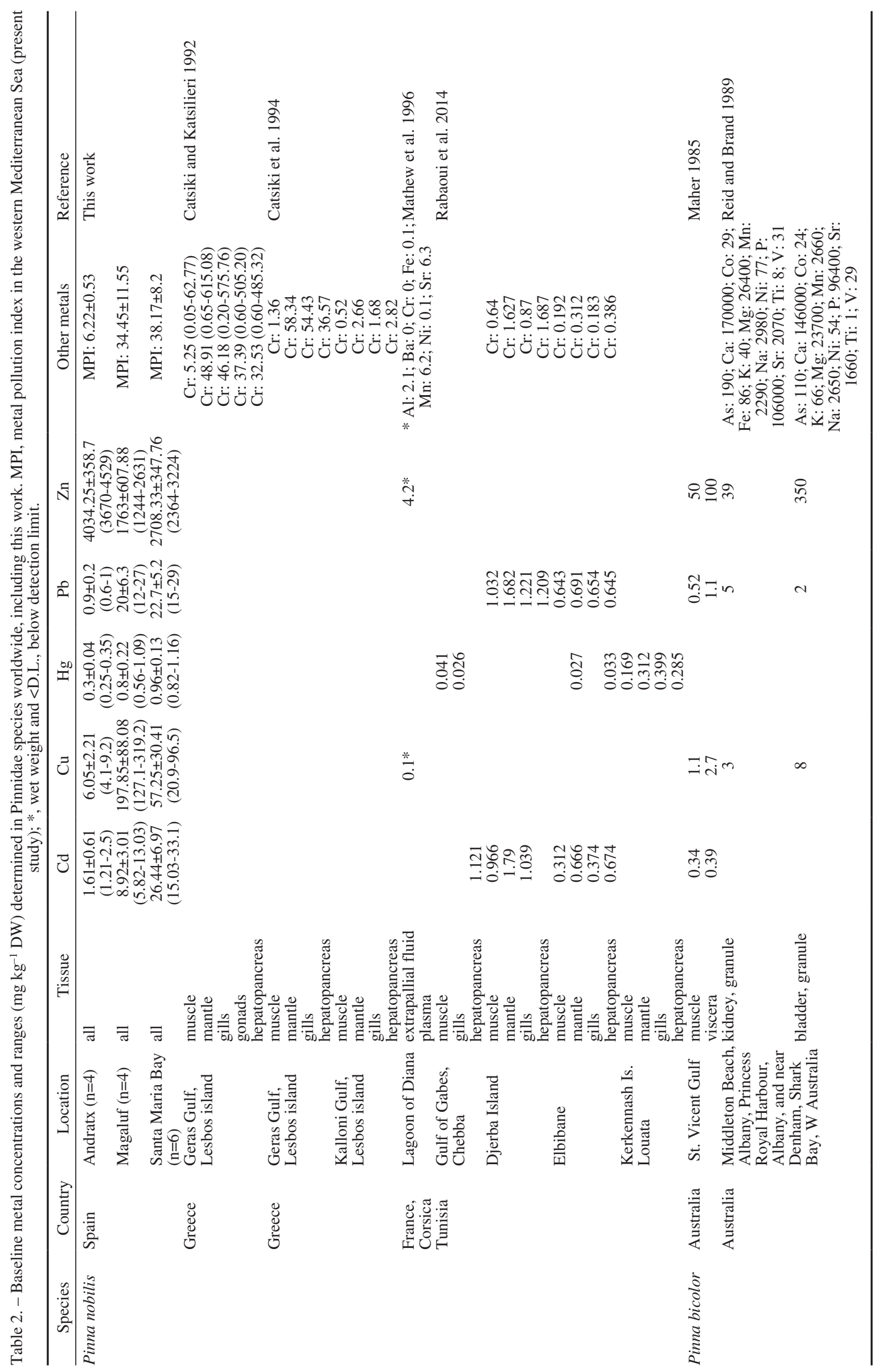




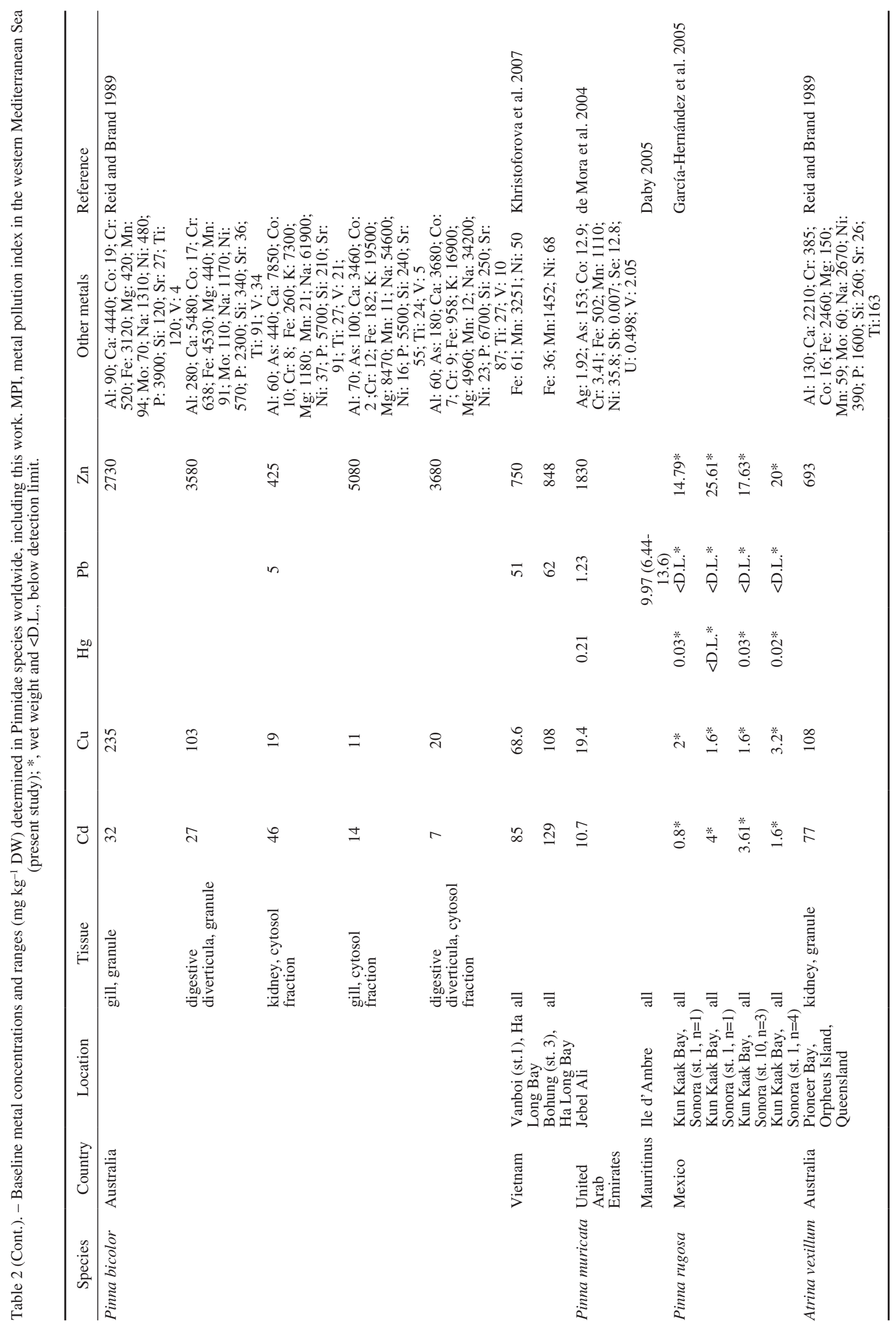




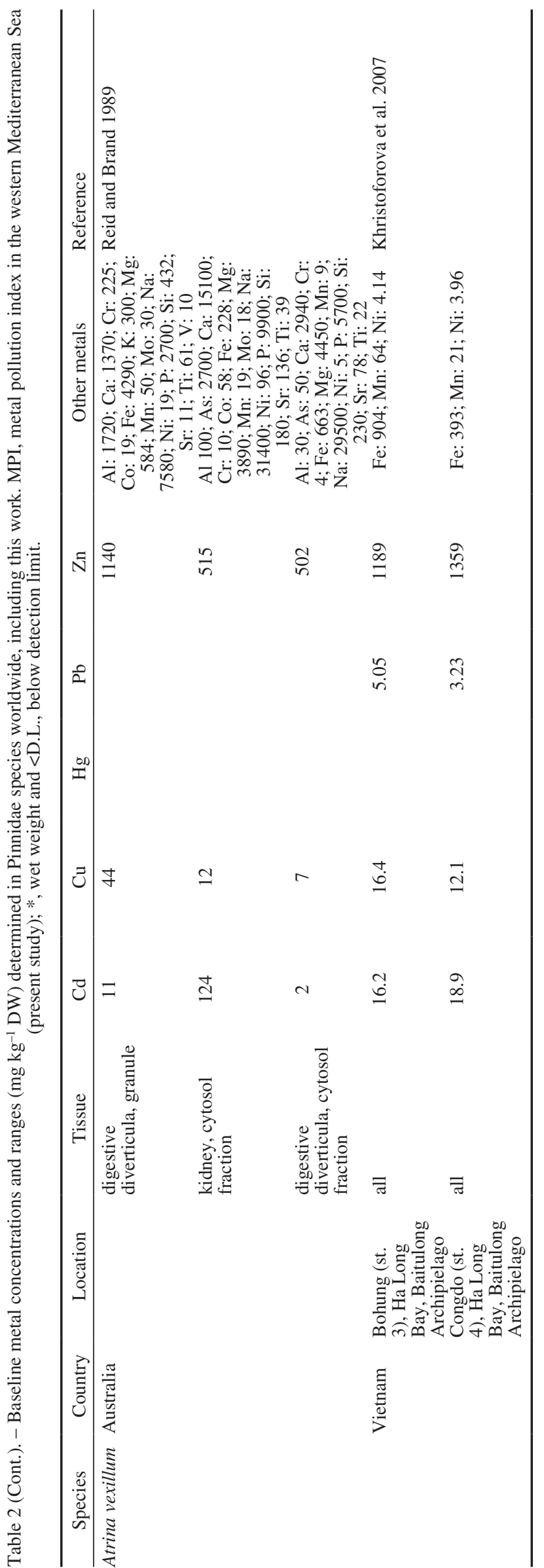

seven metals in P. bicolor from two sites in Vietnam, and encountered slight spatial differences (Table 2).

\section{Pinna muricata}

Two studies reported data for P. muricata. First, de Mora et al. (2004) studied 16 metals in specimens collected on the coast of Jebel Ali in the United Arab Emirates. The study conducted by Daby (2005) provided values of $\mathrm{Pb}$ in Mauritius and the authors proposed that $P$. muricata is a relevant organism to serve as potential bioindicator for $\mathrm{Pb}$ contamination.

\section{Pinna rugosa}

P. rugosa was studied for five metal concentrations $(\mathrm{Cd}, \mathrm{Cu}, \mathrm{Hg}, \mathrm{Pb}$ and $\mathrm{Zn})$, along with sediments and gastropods, after massive die-off episode of fish and molluscs caused by a harmful algal bloom in Kum Kaak Bay (Sonora, Mexico), to investigate the potential relationship between metal leakage from sediments and blooms (García-Hernández et al. 2005).

\section{Atrina vexillum}

This is the only species of the Atrina genus with reported metal concentrations. Reid and Brand (1989) analysed 21 metals in granules and the cytosol fraction of different tissues in Australia, and found differences in the concentrations. Khristoforova et al. (2007) also reported seven metal concentrations in A. vexillum at two sites of Vietnam, but with no noteworthy differences between sites (Table 2).

\section{DISCUSSION}

The present study provides the first dataset on metal levels in P. nobilis in the Balearic Archipelago (western Mediterranean Sea). The overall results evidence high metal concentrations between sampling sites with significant spatial differences. However, it is noteworthy that metal concentrations reviewed in the scientific literature also varied up to three orders of magnitude for some metals between specimens and locations, so our comparisons need to be taken with caution. Unfortunately, in most of the studies nothing is stated, for example, about the number of replicates, shell length (allometric parameters), collection depth or habitat types, or about the sample treatments, making evaluations even more difficult. Therefore, it should be stressed here, that sample collection, transport and laboratory methodologies for performing chemical contaminant analysis of large marine biota specimens such as $P$. nobilis require future agreed scientific protocols, especially for endangered species in the Mediterranean Sea.

Regarding metal concentrations, $\mathrm{Cd}, \mathrm{Hg}$ and $\mathrm{Pb}$ levels were higher in S. Maria Bay, the MPA sampling site (Cabrera Archipelago), than in Majorca Island. However, the mean Cd levels at this site $(26.4 \pm 6.9 \mathrm{mg}$ $\mathrm{kg}^{-1}$ dry weight (DW), Table 2) were much lower (1/5) than those found in Vietnam for P. bicolour (Khristoforova et al. 2007), but almost three times higher than 
P. muricata collected in the United Arab Emirates (de Mora et al. 2004). For Hg and Pb, S. Maria Bay shows the same pattern as Magaluf, though slightly higher $\mathrm{Hg}$ levels were found in S. Maria without significant differences $\left(0.96 \pm 0.13\right.$ and $0.80 \pm 0.22 \mathrm{mg} \mathrm{kg}^{-1} \mathrm{DW}$, respectively). Rabaoui et al. (2014) studied different tissues of $P$. nobilis and found the highest $\mathrm{Hg}$ values in gills (up to $0.169 \mathrm{mg} \mathrm{kg}^{-1} \mathrm{DW}$ ). Correspondingly, similar mean $\mathrm{Pb}$ values determined in S. Maria Bay and Magaluf $\left(23 \pm 5\right.$ and $20 \pm 6 \mathrm{mg} \mathrm{kg}^{-1} \mathrm{DW}$, respectively) were about three times lower than the highest levels found in Vietnam for P. bicolour by (Khristoforova et al. 2007). These $\mathrm{Hg}$ and $\mathrm{Pb}$ levels are the highest in the literature (Table 2). In contrast, the $P$. nobilis specimens collected in the Port of Andratx (Majorca Island) showed much lower values for $\mathrm{Hg}$ and $\mathrm{Pb}$ than the other two sampled sites $(0.30 \pm 0.04$ and $0.9 \pm 0.2 \mathrm{mg} \mathrm{kg}^{-1} \mathrm{DW}$, respectively).

The highest mean $\mathrm{Zn}$ level $\left(4034.3 \pm 358.7 \mathrm{mg} \mathrm{kg}^{-1}\right.$ DW) was found in Andratx and is one of the highest reported in the literature for Pinnidae species, with the exception of the $\mathrm{Zn}$ concentrations of up to $5080 \mathrm{mg}$ $\mathrm{kg}^{-1}$ DW observed by Reid and Brand (1989) in the cytosol fractions in gills of $P$. bicolour. The study, performed in pristine, human-impacted and harbour areas in Western Australia, reports the highest $\mathrm{Cu}$ concentrations in the literature (up to $235 \mathrm{mg} \mathrm{kg}^{-1} \mathrm{DW}$ ), which are close to the mean Cu level $\left(197.85 \pm 88.08 \mathrm{mg} \mathrm{kg}^{-1}\right.$ DW) found at the Magaluf sampling site (Table 2). However, these concentrations in P. bicolor are not given for the whole soft-tissue but for gills, so the specific metal content tissue variability should be considered. Nevertheless, the levels found in P. nobilis at these two sites (Andratx and Magaluf) of Majorca Island point to a high occurrence of $\mathrm{Zn}$ and $\mathrm{Cu}$ in the surrounding environment available for benthic filter-feeders.

In our study areas, the sampling sites were selected taking into account potential differences regarding metal inputs and levels. Both Andratx and Magaluf might be influenced by land, industrial (to some extent), and coastal seasonal tourism uses. Andratx has a recreational port (the Port of Andratx) and Magaluf town discharges treated sewage, mostly from domestic origin. Domestic sewage has been reported to be a source of metal contamination (Wei and Yang 2010), including copper (Santos-Echeandia 2008), and perhaps is the cause of the high $\mathrm{Cu}$ values at the Magaluf site. The high levels of $\mathrm{Zn}$ might be related to the influence of the Port of Andratx, as in the study by Jebali et al. (2014), who exposed $P$. nobilis in a harbour, resulting in increased $\mathrm{Zn}$ concentrations. At the S. Maria bay site, located in the MPA of Cabrera Marine-Terrestrial National Park, there are no evident metal inputs at present, but there was a Spanish military zone used as weapons shooting range until 1991. Jung et al. (2010) studied the contamination and dispersion of trace metals in intertidal sediments around a military weapon shooting range, and found substantial contamination of sediments by $\mathrm{Pb}, \mathrm{Cd}, \mathrm{Cu}$ and $\mathrm{Zn}$, suggesting that those metals were from anthropogenic origin. These high levels of $\mathrm{Cd}, \mathrm{Hg}$ and $\mathrm{Pb}$ might be due to legacy contamination distributed in the benthic habitats of the Cabrera Archipelago.
On the other hand, the levels of metals (expressed as wet weight concentration, ww) found in P. nobilis in the present study for the S. Maria Bay dataset (mean concentration: $5.02 \mathrm{mg} \mathrm{Cd} \mathrm{kg}^{-1}$ wet weight (WW); $0.18 \mathrm{mg} \mathrm{Hg}$ $\mathrm{kg}^{-1} \mathrm{WW} ; 4.37 \mathrm{mg} \mathrm{Pb} \mathrm{kg}{ }^{-1} \mathrm{WW} ; 19 \%$ dry/wet ratio applied) exceed the recommendations of the World Health Organization (WHO 1989) for bivalve molluscs (except for $\mathrm{Hg}$ ) but are below the Food and Agriculture Organization (FAO 1992) standards, despite the large reference range for the latter $\left(1.0 / 0.005-5.5 \mathrm{mg} \mathrm{kg}^{-1} \mathrm{WW}\right.$ [WHO 1989/FAO 1992, respectively] for Cd; $0.5 \mathrm{mg} \mathrm{kg}^{-1} \mathrm{WW}$ [WHO 1989 and FAO 1992] for Hg; and 2.0 / 0.5-6.0 mg $\mathrm{kg}^{-1}$ WW [WHO 1989/FAO 1992]). It should be pointed out here that international standards are set in the context of human health protection for shellfish consumption of commercial species, and this is not the case for $P$. nobilis in the Mediterranean Sea. The high metal levels bioaccumulated in P. nobilis in the Balearic Archipelago indicate different sources of metal contamination, but the potential biological effects in the $P$. nobilis populations and in the benthic ecosystem are still unknown. Elevated metal concentrations could cause a severe reduction or elimination of intolerant species, thereby having a significant effect on the diversity and trophic structure of the biological community (Boening 1999). Metals such as $\mathrm{Cu}$ and $\mathrm{Zn}$ have biological functions and are essential elements for many organisms, although they could be toxic above background levels. The excess of $\mathrm{Zn}$ accumulation in living organisms gives rise to severe metabolic disorders (Du et al. 2011), whilst non-bioactive heavy metals with no known biological functions such as $\mathrm{Cd}, \mathrm{Pb}$ and $\mathrm{Hg}$ can be toxic even at low concentrations (Corbin and Wade 2004). In the case of P. nobilis, high population densities had been found in S. Maria Bay (Vázquez-Luis et al. 2014), where the highest heavy metal levels were found in this study, so the mediumand long-term consequences are uncertain. Surely, some biochemical responses and toxicological effects on the $P$. nobilis could be expected due to the high values of essential and non-essential elements, which should be investigated through a combined chemical and toxicological approach for this species. Metallothionein proteins (MTs) do appear to play roles in the routine metabolic handling of essential $\mathrm{Cu}$ and $\mathrm{Zn}$ and also in the detoxification of intracellular excess amounts of these metals and of non-essential $\mathrm{Cd}, \mathrm{Ag}$ and $\mathrm{Hg}$. Some authors have noted that in a single species the populations that live in a medium polluted by metals have higher concentrations of MT (e.g. Stuhlbacher et al. 1992, Ross et al. 2002); therefore, less sensitive stages corresponded to those with the highest MT concentrations (Pavicic et al. 1994). Different isoforms of MT probably play different physiological roles, and the dependence on MT in detoxification processes varies environmentally and between zoological groups (Amiard et al. 2006). In many species (annelids, molluscs, crustaceans, fish, etc.) induction of metallothionein synthesis by metal contaminants (Ag, $\mathrm{Cd}, \mathrm{Cu}, \mathrm{Hg}$, etc.) has been demonstrated, with the exception of $\mathrm{Pb}$. In fact, in the case of the bivalve Mytilus edulis, $\mathrm{Cd}$ and $\mathrm{Zn}$ induce MT, and after $12 \mathrm{~h}$ of exposure to $\mathrm{Cd}$ and $\mathrm{Zn}$ the MT-10 mRNA levels increased by 3.5 and 4.65, respectively (Soazig and Marc 2003). For 
Ruditapes decussatus the high capacity of metal bioaccumulation in the digestive gland of caged mussels may be related to the high metallothionein synthesis and the rapid sequestration of metals into lysosomes (Serafim and Bebianno 2009). In the case of Pinna nobilis nothing is known about MT, but it could be expected that the high bioaccumulation of metals found in this species may be related to high levels of MT that could be providing protection against toxicity, since a experimental study by Jebali et al. (2014) concluded that $P$. nobilis seems to be a tolerant bivalve species, showing the ability of metal elimination through depuration.

Regarding possible ways of metal uptake in Pinna nobilis, this bivalve is a filter-feeder organism which assimilates nutrients in both dissolved and particulate matter from the surrounding environment. Many studies have demonstrated that it feeds from different food sources, such as the detritus from the water column or from benthic habitats (epiphytes of $P$. oceanica leaves, Lophocladia lallemandii, suspended particulated matter, sedimentary organic matter [SOM] and seagrass) (Kennedy et al. 2001, Cabanellas-Reboredo et al. 2010, Davenport et al. 2011). Recently, Najdek et al. (2013) showed an increasing contribution of phytoplankton and zooplankton food components in the water column detritus with increasing shell size, and concluded that smaller individuals are less food-selective. Further, Trigos et al. (2014) stated that muddy detritus is easily ingested by $P$. nobilis, whilst nearly half of the organic matter contained in the detritus is retained or metabolized, so it is a major source of SOM, whereas phyto- and zooplankton would provide the necessary complements for a healthy diet. Therefore, $P$. nobilis could alternate feeding strategies during seasons typically poor in plankton biomass in the Mediterranean Sea (e.g. winter). However, Alomar et al. (2015) point to a strict pelagic rather than benthic origin of the diet. From these recent studies, it is difficult to figure out the exact routes and sources of metals in $P$. nobilis, although in sites with legacy pollution (such as $\mathrm{S}$. Maria Bay in this study) the benthic routes should also be considered and further investigated. Hence, resuspension processes influencing the higher organic matter ingestion by $P$. nobilis (Cabanellas-Reboredo et al. 2010) may also intensify the uptake of sediment-associated contaminants, so the differences in water column depth and benthic substrate may influence the bioaccumulation processes. The filtration rate in $P$. nobilis is unknown, but it has been estimated that oysters are able to reach rates of filtration of $22 \times 10^{5} \mathrm{~L} \mathrm{~h}^{-1}$ in populations with a density of 157.6 individuals $\mathrm{m}^{-2}$ (zu Ermgassen et al. 2013). Given the size and characteristics of $P$. nobilis, the filtration rates are expected to be high.

When the trace metal levels found in $P$. nobilis (Pinnidae) in this study are compared with those found in other bivalve mollusc species, such as Mytilus galloprovincialis (Mytilidae), a standard bioindicator of the coastal trace metal pollution, benthic $P$. nobilis shows concentrations 30 to 40 times greater for $\mathrm{Cd}$, $\mathrm{Cu}$ and $\mathrm{Zn}$, up to 4 times greater for $\mathrm{Hg}$ and 7 times greater for $\mathrm{Pb}$ in the Balearic Archipelago (Deudero et al. 2007, 2009). It was also determined in a previous study (Sureda et al. 2011, 2013) that polycyclic aromatic hydrocarbon levels in the soft tissues of $P$. nobilis were more than 20 times higher than those in the common $M$. galloprovincialis. In conclusion, the huge differences in metal bioaccumulation between these two bivalve species inhabiting the same coastal environment should be explained mostly in terms of two factors, the specific-species bioaccumulation factors and their feeding behaviours, though metal concentrations and bioavailability are expected to be high in the benthic environment. Further, detritivorous and scavenger gastropods could be accumulating even greater concentrations of metals due to these high concentrations. At present, there are insufficient chemical and toxicological datasets (including distributions of metals in marine sediments) to reach better conclusions. However, future investigations of $P$. nobilis populations in the Mediterranean Sea should agree on methodological scientific protocols to avoid "destruction sampling" of endangered and protected species and allow comparisons at regional and global scales.

Our results highlight the importance of improved monitoring strategies to assess the current status of the marine environments. In Europe, under the Marine Strategy Framework Directive (EU MSFD 2008), the good environmental status of the marine environment needs to be defined. Among the EU MSFD 11 ecosystem descriptors, Descriptor 8 refers to contaminants, including concentrations and biological effects, and it is therefore necessary to evaluate the concentrations of contaminants through an ecosystem-based approach. Until now, we considered 'surrogate species' in the marine ecosystem assessments (e.g. M. galloprovincialis), and therefore underestimated the anthropogenic impact in the ecosystems as a whole, as shown in this study. However, because the entire changing environment cannot be monitored, newer and refined indicators and 'status ecological indices' should be investigated and proposed, in order to help protect and predict humaninduced marine ecosystem changes.

\section{ACKNOWLEDGEMENTS}

This work was supported by the project "Estado de conservación del bivalvo amenazado Pinna nobilis en el Parque Nacional del Archipiélago de Cabrera" (024/2010)" and was partly funded from the European Community's Seventh Framework Programme (FP7/2007-2013) under Grant Agreement No. 287844 project 'Towards COast to COast NETworks of marine protected areas (from the shore to the high and deep sea), coupled with sea-based wind energy potential' (COCONET). We thank the Cabrera National Park staff for permissions and facilities. We also thank E. Álvarez y C. González for fieldwork assistance and A. Gamaza for laboratory work.

\section{REFERENCES}

Alomar C., Vázquez-Luis M., Magraner K., et al. 2015. Evaluating stable isotopic signals in bivalve Pinna nobilis under different human pressures. J. Exp. Mar. Biol. Ecol. 467: 77-86.

http://dx.doi.org/10.1016/j.jembe.2015.03.006

Amiard J.C., Amiard-Triquet C., Barka S., et al. 2006. Metallothio- 
neins in aquatic invertebrates: Their role in metal detoxification and their use as biomarkers. Aquat. Toxicol. 76: 160-202. http://dx.doi.org/10.1016/j.aquatox.2005.08.015

Andral B., Stanisiere J.Y., Sauzade D., et al. 2004. Monitoring chemical contamination levels in the Mediterranean based on the use of mussel caging. Mar. Poll. Bull. 49: 704-712. http://dx.doi.org/10.1016/j.marpolbul.2004.05.008

Benedicto J., Andral B., Martinez-Gomez C., et al. 2011. A large scale survey of trace metal levels in coastal waters of the Western Mediterranean basin using caged mussels (Mytilus galloprovincialis). J. Env. Mon. 13: 1495-1505. http://dx.doi.org/10.1039/c0em00725k

Besada V., Sericano J.L., Schultze F. 2014. An assessment of two decades of trace metals monitoring in wild mussels from the Northwest Atlantic and Cantabrian coastal areas of Spain, 19912011. Env. Int. 71: 1-12. http://dx.doi.org/10.1016/j.envint.2014.05.024

Boening D.W. 1999. An evaluation of bivalves as biomonitors of heavy metals pollution in marine waters. Env. Mon. Assess. 55: 459-470. http://dx.doi.org/10.1023/A:1005995217901

Cabanellas-Reboredo M., Blanco A., Deudero S., et al. 2010. Effects of the invasive macroalga Lophocladia lallemandii on the diet and trophism of Pinna nobilis (Mollusca: Bivalvia) and its guests Pontonia pinnophylax and Nepinnotheres pinnotheres (Crustacea: Decapoda). Sci. Mar. 74(1): 102-110. http://dx.doi.org/10.3989/scimar.2010.74n1101

Catsiki V.A., Katsilieri C. 1992. Presence of chromium in P. nobilis collected from a polluted area. Fres. Envir. Bull. 1: 644-649.

Catsiki V.A. Katsilieri C., Gialamas V. 1994. Chromium distribution in benthic species from a gulf receiving tannery wastes (Gulf of Geras-Lesbos island, Greece). National Centre for Marine Research. A. Kosmas. Hellinikon. Athens 166 04. Greece. Sci. Total Env. 145: 173-185. http://dx.doi.org/10.1016/0048-9697(94)90308-5

Clark R.B. 2001. Marine Pollution. Fifth Ed. Oxford University Press, New York.

Corbin T., Wade S. 2004. Heavy metal concentrations in razorfish (Pinna bicolor) and sediments across northern Spencer Gulf. Environment Protection Authority Adelaide, South Australia.

Daby D. 2006. Coastal Pollution and Potential Biomonitors of Metals in Mauritius. Water, Air Soil Poll. 174(1-4): 63-91. http://dx.doi.org/10.1007/s11270-005-9035-4

Davenport J., Ezgeta-Balic D., Peharda M., et al. 2011. Sizedifferential feeding in Pinna nobilis L. (Mollusca: Bivalvia): exploitation of detritus, phytoplankton and zooplankton. Estuar. Coast. Shelf Sci. 92: 246-254. http://dx.doi.org/10.1016/j.ecss.2010.12.033

de Mora S., Fowler S.W., Wyse E., et al. 2004. Distribution of heavy metals in marine bivalves, fish and coastal sediments in the Gulf and Gulf of Oman. Mar. Poll. Bull. 49 (5-6): 410-424. http://dx.doi.org/10.1016/j.marpolbul.2004.02.029

Deudero S., Box A., March D., et al. 2007. Temporal trends of metals in benthic invertebrate species from the Balearic Islands, Western Mediterranean. Mar. Poll. Bull. 54: 1523-1558. http://dx.doi.org/10.1016/j.marpolbul.2007.05.012

Deudero S., Box A., Tejada S., et al. 2009. Stable isotopes and metal contamination in caged marine mussel Mytilus galloprovincialis. Mar. Poll. Bull. 58: 1025-1031. http://dx.doi.org/10.1016/j.marpolbul.2009.02.011

Du Y., Lian F., Zhu L. 2011. Biosorption of divalent Pb, Cd, and $\mathrm{Zn}$ on aragonite and calcite mollusk shells. Env. Poll. 159: $1763-1768$ http://dx.doi.org/10.1016/j.envpol.2011.04.017

EU Habitats Directive. 2007. Council Directive 92/43/EEC of 21 May 1992 on the conservation of natural habitats and of wild fauna and flora. Annex IV: animal and plant species of community interest in need of strict protection.

http://ec.europa.eu/environment/nature/legislation/ habitatsdirective/index en.htm

EU MSFD. 2008. Council Directive 2008/56/EC establishing a framework for community action in the field of marine environmental policy (Marine Strategy Framework Directive). http://ec.europa.eu/environment/marine/eu-coast-andmarine-policy/marine-strategy-framework-directive/ index_en.htm

FAO 1992 . The state of world fisheries and aquaculture. Food and Agriculture Organization of the United Nations, Electronic publishing policy and support branch. FAO Fisheries and Aquaculture Department 69, 185.
García-Hernández J., García-Rico L., Jara-Marini M.E., et al. 2005. Concentrations of heavy metals in sediment and organisms during a harmful algal Bloom (HAB) at Kun Kaak Bay. Sonora. Mexico. Mar. Poll. Bull. 50: 733-739. http://dx.doi.org/10.1016/j.marpolbul.2005.02.027

García-March J.R. 2003. Contribution to the knowledge of the status os Pinna nobilis (L.) 1758 in Spanish coasts. Mem. Inst. Oceanogr. Paul Ricard 9: 29-41.

Goldberg E.D. 1975. The mussel watch - A first step in global marine monitoring. Mar. Poll. Bull. 6: 111. http://dx.doi.org/10.1016/0025-326X(75)90271-4

Goldberg E.D., Bertine K.K. 2000. Beyond Mussel Match - New directions for monitoring marine pollution. Sci. Total Env. 247: $165-174$ http://dx.doi.org/10.1016/S0048-9697(99)00488-X

Jebali J., Chouba L., Banni M., et al. 2014. Comparative study of the bioaccumulation and elimination of trace metals $(\mathrm{Cd}, \mathrm{Pb}, \mathrm{Zn}$, $\mathrm{Mn}$ and $\mathrm{Fe}$ ) in the digestive gland, gills and muscle of bivalve Pinna nobilis during a field transplant experiment. J. Trace El. Med. Biol. 28(2): 212-217. http://dx.doi.org/10.1016/j.jtemb.2013.12.001

Jung H.-S., Yun S.-T., Choi B.-Y., et al. 2010. Geochemical studies on the contamination and dispersion of trace metals in intertidal sediments around a military air weapons shooting range. J. Soil. Sedim. 10: 1142-1158. http://dx.doi.org/10.1007/s11368-010-0248-9

Kennedy H., Richardson C.A., Duarte C.M., et al. 2001. Diet and association of Pontonia pinnophylax occurring in Pinna nobilis: insights from stable isotope analysis. J. Mar. Biol. Assoc. U.K. 81(1): 177-178. http://dx.doi.org/10.1017/S0025315401003575

Khristoforova N.K., Kavun V.Ya., Latypov Yu.Ya., et al. 2007. Heavy metals in mass species of bivalves in Ha Long Bay (South China sea, Vietnam). Oceanology 47(5): 685-690. http://dx.doi.org/10.1134/S0001437007050116

Lafabrie C., Pergent-Martini C., Pergent C. 2008. Metal contamination of Posidonia oceanica meadows along the Corsican coastline (Mediterranean). Env. Poll. 151(1): 262-268. http://dx.doi.org/10.1016/j.envpol.2007.01.047

Lemer S., Buge B., Bemis A., et al. 2014. First molecular phylogeny of the circumtropical bivalve family Pinnidae (Mollusca, Bivalvia): Evidence for high levels of cryptic species diversity. Mol. Phylog. Evol. 75: 11-23. http://dx.doi.org/10.1016/j.ympev.2014.02.008

Maher W.A. 1985. Trace metal concentrations in marine organisms from St. Vicent Gulf, South Australia. Water Air Soil Poll. 29 (1): 77-84. http://dx.doi.org/10.1007/BF00149330

Mathew S., Paterson J., Gauleja B., et al. 1996. Manganese and "Pinnaglobin" in Pinna nobilis. Comp. Biochem. Physiol. 113B (3): 525-532. http://dx.doi.org/10.1016/0305-0491(95)02077-2

Najdek M., Blažina M., Ezgeta-Balić D., et al. 2013. Diets of fan shells (Pinna nobilis) of different sizes: fatty acid profiling of digestive gland and adductor muscle. Mar. Biol. 160(4): 921-930. http://dx.doi.org/10.1007/s00227-012-2144-x

Neira P., Cobelo-García A., Besada V., et al. 2015. Evidence of increased anthropogenic emissions of platinum: Time-series analysis of mussels (1991-2011) of an urban beach. Sci. Total Environ. 514: 366-370. http://dx.doi.org/10.1016/j.scitotenv.2015.02.016

O'Connor T.P., Beliaeff B. 1995. Recent trends in coastal environmental quality: results from the Mussel Watch Project. Silver Spring M.N. Ed.

O'Connor T.P., Launstein G.G. 2006. Trends in chemical concentrations in mussels and oysters collected along the US coast: update to 2003. Mar. Env. Res. 62: 261-285. http://dx.doi.org/10.1016/j.marenvres.2006.04.067

Pavicic J., Smodis B., Skreblin M., et al. 1994. Embryo-larval tolerance of Mytilus galloprovincialis, exposed to elevated seawater metal concentrations. II. Stage-specific fluctuations in sensitivity toward $\mathrm{Zn}$ and $\mathrm{Cd}$ and their bioaccumulation into veliger larvae. Comp. Biochem. Physiol. C 109(1): 37-46.

Rabaoui L., Balti R., El Zrelli R., et al. 2014. Assessment of heavy metal pollution in the gulf of Gabes (Tunisia) using four mollusc species. Medit. Mar. Sci. 15(1): 45-58.

Reid R.G.B., Brand D.G. 1989. Giant kidneys and metal-sequestering nephroliths in the bivalve Pinna bicolor, with comparative notes on Atrina vexillum (Pinnidae). J. Exp. Mar. Biol. Ecol. 
126: $95-117$.

http://dx.doi.org/10.1016/0022-0981(89)90083-X

Ross K., Cooper N., Bidwell J.R., et al. 2002. Genetic diversity and metal tolerance of two marine species: a comparison between populations from contaminated and reference sites. Mar. Pollut. Bull. 44: 671-679. http://dx.doi.org/10.1016/S0025-326X(01)00333-2

Santos-Echeandia, J., Laglera, L.M., Prego, R., et al. 2008. Copper speciation in continental inputs to the Vigo Ria: Sewage discharges versus river fluxes. Mar. Poll. Bull. 56(2): 308-317. http://dx.doi.org/10.1016/j.marpolbul.2007.10.021

Schultz P.W., Huber M. 2013. Revision of the worldwide Recent Pinnidae and some remarks on fossil European Pinnidae. Acta Conch. 13: 1-164.

Serafim A. Bebianno M.J. 2009. Metallothionein role in the kinetic model of copper accumulation and elimination in the clam $R u$ ditapes decussatus. Environ. Res. 109: 390-399. http://dx.doi.org/10.1016/j.envres.2009.03.001

Soazig L., Marc L. 2003. Potential use of the levels of the mRNA of a specific metallothionein isoform (MT-20) in mussel (Mytilus edulis) as a biomarker of cadmium contamination. Mar. Poll. Bull. 46: 1450-1455. http://dx.doi.org/10.1016/S0025-326X(03)00283-2

Solis-Weiss V., Aleffi F., Bettoso N., et al. 2004. Effects of industrial and urban pollution on the benthic macrofauna in the Bay of Muggia (industrial port of Trieste, Italy). Sci. Total Env. 328: 247-263. http://dx.doi.org/10.1016/j.scitotenv.2004.01.027

SPA/BD Protocol 1995. Annex II of SPA and Biodiversity Protocol. Barcelona Convention Protocol concerning Specially Protected Areas and Biological Diversity in the Mediterranean. http://rac-spa.org/sites/default/files/annex/annex_2_en_2013. pdf

Stuhlbacher A., Bradley M.C., Naylor C., et al. 1992. Induction of cadmium tolerance in two clones of Daphnia magna Straus. Comp. Biochem. Physiol. C 101(3): 571-577. http://dx.doi.org/10.1016/0742-8413(92)90088-O

Sureda A., Box A., Tejada S., et al. 2011. Biochemical responses of Mytilus galloprovincialis as biomarkers of acute environmental pollution caused by the Don Pedro oil spill (Ibiza Island, Spain). Aquat. Toxic. 101: 540-549. http://dx.doi.org/10.1016/j.aquatox.2010.12.011

Sureda A., Tejada S., Box A., et al. 2013. Polycyclic aromatic hydrocarbon levels and measures of oxidative stress in the Mediterranean endemic bivalve Pinna nobilis exposed to the Don Pedro oil spill. Mar. Poll. Bull. 71(1-2): 69-73. http://dx.doi.org/10.1016/j.marpolbul.2013.03.033

Trigos S., García-March J.R., Vicente N., et al. 2014. Utilization of muddy detritus as organic matter source by the fan mussel Pinna nobilis. Medit. Mar. Sci. 15(3): 667-674.

Usero J., Morillo J., Gracia I. 2005. Heavy metal concentrations in molluscs from the Atlantic coast of southern Spain. Chemosphere 59: 1175-1181.

http://dx.doi.org/10.1016/j.chemosphere.2004.11.089

Van der Oost R., Beyer J., Vermeulen N.P.E. 2003. Fish bioaccumulation and biomarkers in environmental risk assessment: a review. Env. Toxic. Pharmac. 13: 57-149. http://dx.doi.org/10.1016/S1382-6689(02)00126-6

Vázquez-Luis M., March D., Álvarez E., et al. 2014. Spatial distribution modelling of the endangered bivalve Pinna nobilis in a Marine Protected Area. Medit. Mar. Sci. 15(3): 626-634.

Wei B., Yang L. 2010. A review of heavy metal contaminations in urban soils, urban road dusts and agricultural soils from China. Microch. J. 94(2): 99-170. http://dx.doi.org/10.1016/j.microc.2009.09.014

World Health Organization (WHO). 1989. Heavy metals environmental aspects. Environment Health Criteria, No 85. Geneva, Switzerland

WoRMS, World Register of Marine Species. 2014. Available from http://www.marinespecies.org at VLIZ. Accessed 2014-10-20

Zavodnik D., Hrs-Brenko M., Legac M. 1991. Synopsis on the fan shell Pinna nobilis L. in the eastern Adriatic Sea. In: Boudouresque C.F., Avon M., Gravez V., (eds) Les Espèces Marines à Protéger en Méditerranée. Gis Posidonie publ. Marseille pp. 169-178.

zu Ermgassen P.S.E., Spalding M.D., Grizzle R.E., et al. 2013. Quantifying the Loss of a Marine Ecosystem Service: Filtration by the Eastern Oyster in US Estuaries. Estuar. Coast. 36: 36-43. http://dx.doi.org/10.1007/s12237-012-9559-y 